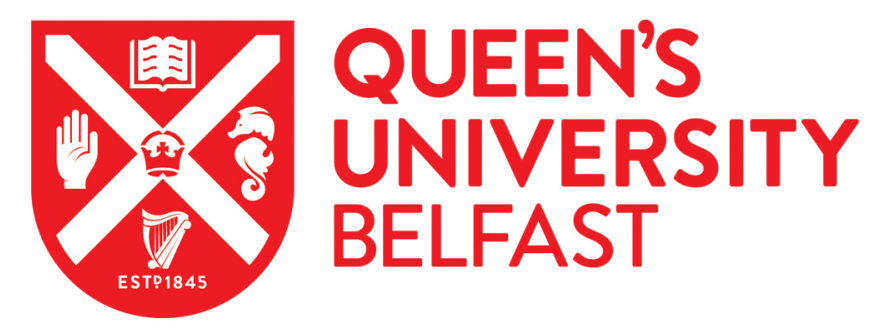

\title{
Collaborative Scholarship on the Margins: An Epistolary Network
}

Hannan, L. (2014). Collaborative Scholarship on the Margins: An Epistolary Network. Women's Writing, 21(3), 290-315. https://doi.org/10.1080/09699082.2014.925031

\author{
Published in: \\ Women's Writing
}

\section{Document Version:}

Peer reviewed version

Queen's University Belfast - Research Portal:

Link to publication record in Queen's University Belfast Research Portal

\section{Publisher rights}

This is an Accepted Manuscript of an article published by Taylor \& Francis in Women's Writing on 30 July 2014, available online: http://www.tandfonline.com/doi/abs/10.1080/09699082.2014.92503

\section{General rights}

Copyright for the publications made accessible via the Queen's University Belfast Research Portal is retained by the author(s) and / or other copyright owners and it is a condition of accessing these publications that users recognise and abide by the legal requirements associated with these rights.

Take down policy

The Research Portal is Queen's institutional repository that provides access to Queen's research output. Every effort has been made to ensure that content in the Research Portal does not infringe any person's rights, or applicable UK laws. If you discover content in the Research Portal that you believe breaches copyright or violates any law, please contact openaccess@qub.ac.uk. 


\section{COLLABORATIVE SCHOLARSHIP ON THE MARGINS: An epistolary network}

This article explores collaborative scholarship on the margins of intellectual life in eighteenth-century England via a close examination of George Ballard's collected correspondence from women letter-writers. Ballard was both a man of trade and an antiquary and his modest social status inhibited his freedom to move in scholarly circles. Ballard's only published book documented the lives and works of "learned ladies" of Britain from the fifteenth to the eighteenth centuries and his female correspondents included the Anglo-Saxon scholar Elizabeth Elstob. His collected correspondence provides an insight into a network that operated outside of the major institutions of scholarship and far from the coffee houses of metropolitan life, but which supported its participants in their intellectual endeavours. By examining the collection materially, and by plotting the correspondents geographically, a more precise picture can be drawn of how women and lower status men could engage in intellectual life from the peripheries of scholarly society. 
On his death, antiquary and stay-maker George Ballard (1705/6-55) left the Bodleian Library a letter book containing correspondence from female friends. ${ }^{1}$ The letter book provides lasting evidence of an epistolary network, which supported Ballard's publication by subscription of a book about learned women in history. Over decades, Ballard earned respect amongst the antiquarian community for his dedication to, and aptitude for, historical research. However, like the women he corresponded with, Ballard was unable to occupy a comfortable position within scholarly society. For reasons of social status or gender, most of the individuals represented in this letter book pursued their interests from the margins of eighteenth-century intellectual life.

Through a detailed analysis of the contents of the letter book, light will be shed on how Ballard's epistolary community operated within the broader context of eighteenthcentury cultural production. The geography of the network, the material construction and content of the letters, and the relationships between the correspondents will all be analysed in order to consider the modus operandi of the group. This investigation moves beyond the bounds of existing scholarship on George Ballard as an antiquary and champion of learned women by thinking through the societal conditions that facilitated his work. In the process, this article contemplates the interaction of class status, gender, geography, and intellectual production in eighteenth-century England.

\section{The letter book}

The letter book is a large volume of collated correspondence, still in its eighteenthcentury binding, with a title page listing the names of eighteen women and claiming of its contents: "one hundred and forty original letters". The cardboard edges are frayed but the oxblood stained spine with formal ridges and embellishment in gold speaks to the book's material significance. The first page is crisply framed by a hand-drawn double ruled line, aggrandising the names written within. Some names are familiar: the early eighteenthcentury Anglo-Saxon scholar, Mrs Elstob, ${ }^{2}$ heads the list; further down: the intellectually well-connected Mrs Delany, ${ }^{3}$ known variously for her support of worthy women and her fine decoupage artworks. But, likewise, names largely unknown to scholarship sit alongside Elstob and Delany - betraying the existence of broader epistolary networks operating beneath the surface of eighteenth-century intellectual life.

This collection of correspondence started life as several bundles of letters, received from Ballard's friends and supporters of his subscription publication Memoirs of Several Ladies of Great Britain. This book recorded the lives of sixty-four women who had distinguished themselves by their intellectual activities from the fifteenth to the eighteenth centuries. Ballard described his purpose in publishing Memoirs as an attempt to preserve "from oblivion the memory of illustrious persons". ${ }^{4}$ The book was finally published in 1752, the date at which the letter-writing in Ballard's manuscripts runs out. This volume of letters, transformed from scattered correspondence, collated and arranged by epistolary author, was left to record something greater than its parts. For the reader today this could be many things: a record of the history of subscription publishing, a trace of antiquarian curiosity, or the surviving remnant of a largely female epistolary network. Most of the letters still have their address page, sealed with wax and stamp, tracing the geographies of this predominantly south-western English network. These letter-writers, enjoined by their shared interest in antiquarian scholarship, followed their instincts carefully dating every epistle and its place of writing, recording its vital details for its 
first, or future, reader. Some letters were annotated by Ballard, reminding himself or posterity, of the names and subjects that would become obscure with the distance of years. Ballard was quoted as saying of the letters that he had "very carefully bound [them] up with my own hands". ${ }^{5}$ The collection came to the Bodleian Library just one year after Ballard's demise and at his bequest, a further sign of his hopes for its future readership. ${ }^{6}$

Whilst Ballard's letter book has been mined by historians for the information it contains on important historical figures, such as the aforementioned early bluestocking scholar, Elizabeth Elstob, it has never been studied as a whole, including the letters penned by lesser-known individuals in Ballard's circle of acquaintance. ${ }^{7}$ By using the letter book as a starting point three issues will be explored: the antiquarian activities of scholars working on the margins of eighteenth-century intellectual life, the geographies of an epistolary network, and the interconnected and intellectually-motivated relationships of the letter-writers.

\section{The context: people, places, and publishing}

Eighteenth-century intellectual life was diffuse, incorporating the formal institutions of universities and societies; social spaces such as coffee shops, inns, and drawing rooms; and a vibrant culture of letter-writing. These diverse places and spaces were inhabited by a correspondingly varied population - individuals who, by the benefit of birth or personal interest, used the expanding print industry to avail themselves of specialist knowledge. As Justin Champion has identified for the seventeenth century, "a broader cultural system" of erudition operated in society which made it possible for the determined nonelite scholar to permeate the ranks of the learned. ${ }^{8}$ The field of antiquarian study was no exception. However, those who did not fit the ideal of the gentleman scholar were easy targets for ridicule and experienced much greater difficulty in accessing the people, funds, and source materials required for serious study.

Patterns of sociability common in urban centres like London or the university cities certainly facilitated intellectual exchange, but antiquarian scholarship was also deeply rooted in the provinces. As Rosemary Sweet notes:

Scores of antiquaries across the country were engaged in pursuing the history and antiquities of their localities, recording the physical appearance of their church, tracing out Roman roads, collecting hoards of coins or excavating barrows. ${ }^{9}$

Moreover, antiquarian scholarship was a popular pursuit amongst the gentry, keen as many were to demonstrate the importance and longevity of their own family heritage within the context of their locality. These gentleman scholars contributed to the development of county history and provided regional foci for the amassing of antiquarian knowledge. ${ }^{10}$ However, as Rosemary Sweet has stressed, whilst antiquarianism relied upon the support of the gentry and traded on its status as a gentlemanly pastime:

the most active antiquaries came from the ranks of the lesser gentry and those who merged with the professional classes, rather than from the great landowners and the aristocracy. ${ }^{11}$ 
Eighteenth-century intellectual life was, therefore, to be found in both urban and rural society and, via the mechanisms of patronage and commercial book selling, included individuals of modest social standing and women as well as the landed male elite. ${ }^{12}$

This was the context in which George Ballard and his network of female correspondents operated. Ballard himself engaged in a range of typical activities for an antiquary of his time: he collected coins and books, learned Old English and later Latin, and wrote an historical account of his local church in Campden. ${ }^{13}$ As will be discussed below, Ballard's epistolary network was located in the south-west of England, predominantly in the neighbouring counties of Gloucestershire, Worcestershire, and Warwickshire. Their regional location was no barrier to antiquarian investigation, but Ballard's position as a man of trade did exclude him from the more intimate social circles of local landed gentry and, for most of his life, barred his access to the Bodleian Library. ${ }^{14}$ Likewise, aside from the exceptional Elizabeth Elstob, Ballard's female contacts were not in a position to pursue scholarship from within the formal intellectual institutions of the day. Moreover, by the 1730s, Elstob herself had long been separated from the manuscripts she had researched in her youth, and was unable to create the circumstances that would re-admit her to these historical collections. Nevertheless, like the rest of eighteenth-century society, Ballard's circle made extremely good use of correspondence to further their particular interests. As Rosemary Sweet highlights:

It was this flourishing network of exchange and correspondence, as much as the Society of Antiquaries itself, which sustained the antiquarian enterprise. It facilitated the study of antiquities by encouraging the free exchange of artefacts, manuscripts and books, the performance of services (such as making transcriptions, identifying references) and the opportunity to exercise patronage by which the recipient was assisted and the credit and reputation of the patron was enhanced. ${ }^{15}$

For Ballard and his friends, letter-writing was absolutely central to their experience of research and publication. ${ }^{16}$

Ballard's letter book presents the reader with a provincial and predominantly female network that engaged collaboratively with the processes of scholarly research and subscription publication. The letters foreground the efforts of women who are not wellknown to histories of intellectual life, but in the background, the gravitational pull of culturally powerful individuals, like Delany and the Duchess of Portland, can be felt. The letter book illuminates scholarship on the margins, legitimate in the context of regionspecific antiquarian inquiry, but distant from urban coffee houses and societies, or the great houses of the patrons of eighteenth-century cultural life. Whilst no-one in the immediate circle was elevated enough to act as a patron for Ballard's publication project, individuals did collect subscriptions for Ballard's book and petition their friends and acquaintances in an attempt to secure more high level support. ${ }^{17}$ Here, the context in terms of patronage and subscription publishing will be briefly explored to clarify the work of this epistolary network in relation to broader trends in scholarly production.

Historical treatment of the subject of eighteenth-century patronage has traditionally argued that the century saw a shift away from an oppressive model of aristocratic patronage towards one of commercial economy in the production of culture. ${ }^{18}$ 
However, scholars such as Paul Korshin and Dustin Griffin have both amply demonstrated that there was no wholesale rejection of the system of patronage in this period. For Korshin, patronage "was entrenched, through custom, convenience, and plain necessity"19 and as Griffin puts it, the system was "roomy enough to allow for resistance and manipulation on the part of the writers who worked within it" 20 adding:

what is most striking about the system in operation is that it was always a site of contestation, as authors and patrons, later joined by booksellers and critical reviewers, jockeyed for position and for authority. ${ }^{21}$

As such, the experience of Ballard and his women friends can be viewed against a backdrop of scholarly work that was influenced not only by the commercial pressures of book selling, but also by the more traditional considerations of patronage. The fact that Ballard chose to publish Memoirs by subscription points to two issues: the first, he was without a major benefactor and second, the publication of antiquarian books frequently relied on this method - being generally printed in short runs for very particular readers. ${ }^{22}$ As David Hunter and Margaret Seares have highlighted for the publishing of music, subscription was the only option for authors (or composers) who did not have either income or a loan to cover the up-front costs of printing. ${ }^{23}$

The example of the poet Ann Yearsley, writing in the second half of the eighteenth century, provides a useful comparison with Ballard's endeavour. ${ }^{24}$ Yearsley's project was literary rather than antiquarian, but as a woman with no private means she experienced a double bind in her efforts to publish her work. As has been noted by historians, there were many fewer favours that could be bestowed upon a woman by a patron, women not being eligible for public office or any number of other professional roles. Nevertheless, Yearsley secured the patronage of the writer and philanthropist, Hannah More, ${ }^{25}$ and then very publicly rejected that support in the mid-1780s after publishing three editions of Yearsley's Poems, on Several Occasions under More's wing. Yearsley's first books were published via subscription using More's illustrious circle of acquaintances to provide the contributions. ${ }^{26}$ Yearsley's break with More has been viewed as a bid for authorial independence, but Frank Felsenstein's analysis of letters in the West Yorkshire archive reveal that, in fact, Yearsley carefully secured new patronage from alternative sources and continued to rely on the active advocacy of a network of friends to continue her literary work. ${ }^{27}$ Yearsley's example is also revealing of how subscription publishing interacted with patterns of patronage. As Felsenstein highlights:

All three of Yearsley's volumes of poetry were published by subscription, with well over a thousand subscribers for Poems, on Several Occasions (1785), just under five hundred for Poems, on Various Subjects (1787), and one hundred and twenty-eight listed names for The Rural Lyre (1796). ${ }^{28}$

This reduction in numbers of subscribers might be explained by a growing confidence on the part of the publisher that Yearsley's books would sell or, alternatively, that Yearsley over time - received more direct financial support from her patrons, making the numbers of additional subscribers less critical. ${ }^{29}$

Yearsley's careful cultivation of her network of supporters (often via letterwriting), and successful negotiation of a difficult market for a financially dependent 
female writer, is interesting when compared with Ballard's circumstances. Whilst Ballard himself was able, ultimately, to take up a modest position within the University of Oxford, he spent the majority of his working life struggling financially - spending a diminishing amount of time working at his trade and more time on his studies. He was less successful than Yearlsey in courting patrons who would dig deep into their pockets. The Yearsley example also points to the particular dynamics of scenarios involving women: both as the talent and as the patron in her case. Whilst women did stand at a substantial disadvantage in seeking financial support it was possible for them to do so. Moreover, women acted as patrons too - sometimes favouring members of their own sex as writers to champion. For Ballard and Yearsley, the frenetic letter-writing of female friends proved invaluable in the acquisition of support for publication.

\section{George Ballard}

Born in Chipping Campden in Gloucestershire, George Ballard was the son of a chandler and a midwife and a member of a large family, with four brothers and three sisters. Ballard lost his father, Samuel, when he was only four years old and suffered with recurrent ill health as a child. On account of his perceived physical weakness, Ballard was apprenticed as a maker of women's clothing, but despite this training he pursued an avid interest in books and coins and taught himself Old English and Latin outside of his hours of work. ${ }^{30}$ George Ballard shared his passion for antiquity with his elder sister, Elizabeth, who followed her mother into the profession of midwifery. ${ }^{31}$ Despite his modest personal circumstances, antiquarianism and the publishing of Memoirs consumed Ballard's time and energy and, unsurprisingly, represented the defining themes of his collected correspondence.

During his lifetime, Ballard made several key acquaintances that facilitated his movement amongst antiquarian circles and, ultimately, secured his admittance to Magdalen College, Oxford in 1750. In particular, the churchman and antiquary Dr Charles Lyttelton proved a highly supportive contact for Ballard and the two men conducted a warm and lengthy correspondence. Nevertheless, as Sweet emphasises: "antiquarianism was not class neutral" and Ballard's position within the broader community of scholars had to be carefully negotiated. ${ }^{32}$ For example, whilst Lyttelton was happy to maintain a regular correspondence with Ballard, the two did not mix socially. The fact that Ballard only gained admittance to the Bodleian Library as late as 1747 was a sign of the marginal position of someone of his class, and when he entered the University of Oxford three years later - and at the mature age of forty-four - he did so as a clerk rather than as a fellow. These patterns of inclusion and exclusion were mirrored in the make-up of the membership of the Society of Antiquaries, which drew about a third of its fellows from the population of gentlemen of private means alongside a significant number of clergymen. ${ }^{33}$ The Society also opened its doors to some professions - lawyers, medics and army officers were all to be found amongst its members - but by and large, the Society did not admit men - like George Ballard - who made their living by trade. ${ }^{34}$ However, for Ballard, without the means to travel abroad, antiquarian research still offered opportunities - focused as it often was on the history of the British Isles. ${ }^{35}$ This emphasis on conducting detailed, local studies diminished the disadvantages of being resident far from London or other key urban centres and made it possible to build a recognisable expertise in a discrete field of enquiry. 
Ballard's position on the periphery of mainstream scholarship may have motivated his sympathy for the difficulties experienced by generations of "learned ladies" in their pursuit of knowledge. As Ruth Perry has remarked "Ballard wrote about women who were, like him, perennial students, amateurs in the groves of academe. ... The conditions of their intellectual lives were similar to the conditions of his intellectual life." 36 Indeed, of the 400 subscribers to Ballard's book, Memoirs of Several Ladies, 143 of them were women and several of the women letter-writers in Ballard's letter book were instrumental in recruiting subscribers. ${ }^{37}$ Despite this communal effort, the letter book is also revealing of the differences in both social status and intellectual clout that affected the women in Ballard's network. Nevertheless, as Elizabeth Elstob herself acknowledged, where an intellectual drive was shared, differences of status could be, at least, overlooked:

The modest and humble account you are pleas'd to give of yourself, raises my esteem for you much higher than it was before there being very few to be found who will undervalue themselves. I am intirely of opinion, by the Polite Letters I have receiv'd from you that let your employment be what it will you must be a Person of good Birth good Education and an Excellent Genius. ${ }^{38}$

Elstob was right, she could not have met with a more "passionate lover of History and Antiquity, Biography, and Northern Literature” than Ballard. ${ }^{39}$ The surviving correspondence and diary entries of several eminent scholars of the period confirm that Ballard's skill and dedication as an antiquary and biographer were recognised widely in the antiquarian community. Even the antiquary Thomas Hearne's gnomic diary entries give a sense of the recognition Ballard received as a man of scholarly merit. On the 21 January 1732, he noted that: “ $\mathrm{M}^{\mathrm{r}}$ Ballard of Campden hath a very fine Collection of Coins, found at Cirencester, of $\mathrm{w}^{\mathrm{ch}}$ he hath sent me a List according to the order of time." 40 On 30 June of the same year, Ballard's name appears again - this time with a more detailed record of their meeting:

He told me last night that among $\mathrm{M}^{\mathrm{r}}$ Graves’s coins bought by Roger Gale Esq. were several gold ones. He shewed me several coins, Roman and English. Some of the Romans were spurious. He had a brass one of Julius Caesar, which $\mathbf{M}^{\mathrm{r}}$ Ballard met with at London, where he had now been on foot, but I do not take it to be genuine. He said $\mathrm{M}^{\mathrm{r}}$ West hath a prodigious collection of curiosities, among which a very extraordinary collection of Prints, the best he said of any particular person in England. ${ }^{41}$

Hearne completed his entry with a remark that revealed both the generous-spirited sharing of documents that was common amongst antiquaries and also the trust that more established scholars placed in Ballard's competence.

$\mathrm{M}^{\mathrm{r}}$ West, who hath got $\mathrm{M}^{\mathrm{r}}$ Graves's private Papers as well as others, will let $\mathbf{M}^{\mathrm{r}}$ Ballard have any of them whosoever that relate to Campden. $\mathrm{M}^{\mathrm{r}}$ Ballard may be a proper person to have the use of them, in order to write the antiquities of Campden. $\mathrm{M}^{\mathrm{r}}$ Ballard hath written an account of the antiquities of Campden Church in a Letter he wrote to me. ${ }^{42}$ 
Whilst George Ballard could not fully participate in the mainstream of antiquarian scholarship, his talents and dedication were certainly acknowledged by those who did and, very gradually, this recognition gave Ballard access to the collections and the people who could further his studies.

\section{George Ballard's legacy}

Despite George Ballard's position on the margins of scholarly life, Memoirs has had a lasting influence on historians' understandings of early learned women. As Margaret J.M. Ezell has amply highlighted, the biographical details presented in Ballard's text subsequently became a key source for commentators wishing to discuss the work of early modern women writers. ${ }^{43}$ Ezell argues that this process of recycling Ballard's material in later histories has had a lasting influence on the construction of the early modern woman writer in literary history. ${ }^{44}$ In particular, Ezell's analysis emphasises Ballard's framing of his subjects as pious women, in the protestant tradition, and argues that far from making an objective compilation of all known learned women, Ballard imposed a selection process that has since served to obscure the contributions of women who did not match his vision of the learned lady. ${ }^{45}$ As Ruth Perry writes:

Ballard's learned ladies were respectable and pious. They tended to be martyrs of the Church of England or staunch Anglicans ... They were usually adept at one or more of the classical languages, which they used in the service of religious commentary. They were generally not fiction writers or playwrights; they concerned themselves more with theology than with romance. ... Many of them were married women; most were well-to-do; none were self-supporting writers in the Grub Street marketplace. ${ }^{46}$

Ezell also highlights the gaps in Ballard's coverage, most particularly concerning the "commercial female playwrights: Aphra Behn, Mary Pix, and Susannah Centlivre" and "professional women writers such as Hannah Woolly". ${ }^{47}$ Whilst Ezell and Perry rightly detect that Ballard selected certain women writers over others according to a particular view of who constituted a truly learned lady, this seems in keeping with the task he had at hand. After all, most literary historical scholarship relies on the use of some category of writer or genre to provide its framework for analysis. So whilst it is no surprise that George Ballard failed to rise above such common techniques of literary categorisation, it is still extremely valuable to recognise the legacy left by his particular selection of "learned ladies". Perhaps, for Ballard, being "learned" was just different from being "literary" and whilst demonstrable piety might have encouraged inclusion, a more important criterion was the intellectual pursuit to which a learned mind was applied. Ballard's own subtitle read "[ladies] who have been celebrated for their writings or skill in the learned languages arts and sciences". ${ }^{48}$ Perry describes Ballard's women as follows:

They read Scripture in its original languages, wrote satiric imitations of classical texts, composed new translations, wrote essays upon traditional subjects, and even made painstaking calligraphic copies of the antique hand writings found in illuminated manuscripts. ${ }^{49}$ 
These were not women who made their living by the pen and, considering the subjects they excelled in, were less likely to be able to do so than those who wrote fiction or for the stage. Ballard's learned women were more in the mould of Elizabeth Elstob than they were Mary Pix. So, whilst the legacy of Memoirs may have seen some women writers overlooked in subsequent literary histories, it was Ballard's explicit intention to privilege the scholarly over the literary - but to do so in an inclusive manner. In fact, throughout, Ballard persisted in making explanations for why women may have been ignored by previous works, showing in the process his own methods for tracing their histories. With his inclusion of the sixteenth-century sisters Lady Anne, Lady Margaret and Lady Jane Seymour, Ballard explained why other authors had not highlighted their intellectual merits:

That neither Leland, ${ }^{50}$ Bale $^{51}$ or Pits ${ }^{52}$ take any notice of these ladies is not to be wondered at, when it is considered that Bale brought his work no lower than the year 1548: Leland was deprived of his reason, and died distracted soon after: and Pits had such an extravagant aversion to protestantism that he purposely omitted all the writers which were of that opinion. ... However, I have taken some pains in order to trace them out, and if I am not deceived in my conjecture ${ }^{\dagger}$, they were the daughters of Edward Seymour due of Somerset, and uncle to King Edw. VI. by Anne his second wife, daughter to Sir Edward Stanhope. ${ }^{53}$

† Since the writing of this, I find my conjecture supported by the authority of Mr. Fulman, in the $15^{\text {th }}$ volume of his manuscript collections, in Corpus Christi College Archives.

It is natural that Ballard should have read the work of John Leland, John Bale and John Pits in his preparation for writing Memoirs. The vast body of work left by these three men was an invaluable inheritance for the antiquarians of Ballard's generation. Leland and Bale were contemporaries and when Leland died in 1552, Bale campaigned for the preservation of his papers. ${ }^{54}$ John Bale was the first of very many historians and antiquaries to acknowledge the debt he owed to John Leland. Likewise, Bale's own papers joined the ranks of the major libraries and the "antiquarian learning contained within his comprehensive bibliographies continues to influence scholars." 55 Nevertheless, Ballard felt justified in criticising these men's omissions and, in so doing, strengthening his own position as an independent and diligent scholar. In this way, Ballard's central argument about the range of female figures that have been wrongly overlooked is not only explicit in the Preface, but also ingrained in the text as a whole. Later, in a letter to Dr Lyttelton, Ballard reported several negative reviews of his recently published book accusing him variously of a staunchly Tory leaning and a strong Whig allegiance. Baffled by these conflicting criticisms, Ballard defended his neutrality in relation to his choice of learned women:

I dare not censure or condemn a good thing merely because it borders upon the Church of Rome. I rather rejoice that she [Mrs Hopton] retains any thing I can fairly approve. ... I cannot for my life perceive that I have said any thing of that excellent woman, which she does not merit. ${ }^{56}$ 
Whilst Ballard did operate within certain criteria in his choice of learned women prominent attributes being a facility with Ancient languages, a propensity to study scripture, and the production of transcriptions - his claims to objectivity were not absurd. Within his own framework and with the sources he had available, Ballard did set out to write a book celebrating the most learned women in history, whether they had been previously recognised by scholarship or not. And in those imperfect conditions, Ballard was able to make an extremely influential contribution to the historiography of female intellectual achievement.

\section{George Ballard's network}

The list of names on the title page of Ballard's letter book reads as follows:

"One Hundred and Forty Original Letters From

Mrs Elstob
Mrs Hopkins
Mrs Chapone
Miss Chapone
Mrs Talbot
Mrs Millar
Mrs Trenchard
Mrs Delany
Mrs Dewes
Mrs Rawlins
Mrs Thornton
Mrs Turner
Mrs Cornwallis
Mrs Crispe
Lady Fox
Lady Keyte
Countess of Hertford
Count. of Warwick etc”

If confirmation were needed of the importance of these women to Ballard's publishing project, the dedications in Memoirs provides it: both Sarah Talbot and Mary Delany are personally acknowledged. ${ }^{57}$ Letters by Elizabeth Elstob, Sarah Chapone, Anna Hopkins, Sarah Talbot, and Anne Dewes contribute the majority of the letter book's contents, numbering nearly one hundred of the one hundred and forty there contained. Ballard's letter book has been examined by historians most thoroughly for the letters written by Elizabeth Elstob and, to a lesser extent, for those by Sarah Chapone. ${ }^{58}$ Indeed, Elstob's letters provide the only extant evidence of the Anglo-Saxon scholar's later life - after the high point of her early academic achievements had passed and she was left to support herself through teaching. The letters are an extremely intimate portrayal of a woman scholar's frustrations with a life that no longer afforded access to historical manuscripts and the opportunity to study them first-hand and publish her findings - freedoms which had marked her early adulthood. But whilst Elstob did not return properly to her studies, 
the correspondence in Ballard's letter book reveals that she did reconnect with a community of intellectually motivated individuals who recognised her value as a scholar. At this point, it is worth mentioning the connections that existed between the women on the list - aside from their mutual interest in Ballard and his work. For one, Mary Delany and Anne Dewes were sisters and Delany had come into contact with Sarah Chapone after reading a piece of her writing, most likely "The Hardships of the English Laws in Relation to Wives”, which was published anonymously in May $1735 .{ }^{59}$ In Mary Delany's later life she spent her summers at Bulstrode in Buckinghamshire with the Duchess of Portland, her close friend and the woman who ultimately relieved Elstob's financial privation by offering her a position as governess within her household. ${ }^{60}$ The fact that Mary Delany had been so impressed with Sarah Chapone's intellectual abilities no doubt aided Chapone's efforts to get Elizabeth Elstob's plight recognised by the Duchess of Portland. Delany and the Duchess of Portland were certainly the most powerful and influential women involved in this epistolary network (both in terms of their financial means and their intellectual influence) although neither were central figures in Ballard's female circle of acquaintance.

It was George Ballard himself who introduced Sarah Chapone and Elizabeth Elstob in the mid-1730s at which point Chapone began to campaign for Elstob's financial relief on account of her reduced situation in life and the deleterious effect this had on her intellectual work. Sarah Chapone "also interested her old girlhood friends, Anne Dewes and Mary Pendarves, the former Anne and Mary Granville, on Mrs Elstob’s behalf.”61

It should also be noted, that in 1741 Anna Hopkins' letters to Ballard were written from Evesham, where she had presumably come into contact with Elstob, who was mistress of the local elementary school. Hopkins was frequently mentioned in Elstob's letters to Ballard of the late 1730s and she played a crucial role in first securing subscriptions for Ballard's publication and, later, in encouraging sales. It is also clear that Anna Hopkins was in close contact with Anne Dewes, in August 1741 Hopkins wrote to Ballard:

I had the happiness of being six weeks with the most ingenious, and agreeable $\mathbf{M}^{\mathrm{rs}}$ Dewes last winter, we often talk'd of you, if she comes to Evesham, I believe we shall make the Visit, and she bid me tell you that she shou'd be very glad to see you at Bradley-Green. ${ }^{62}$

The varied bonds of family, friendship and patronage that can be found amongst Ballard's epistolary network give a sense of how these individuals came to exchange so many letters, but they also reveal the diversity that could exist within a determined correspondent's circle of acquaintance. 


\section{An epistolary geography}

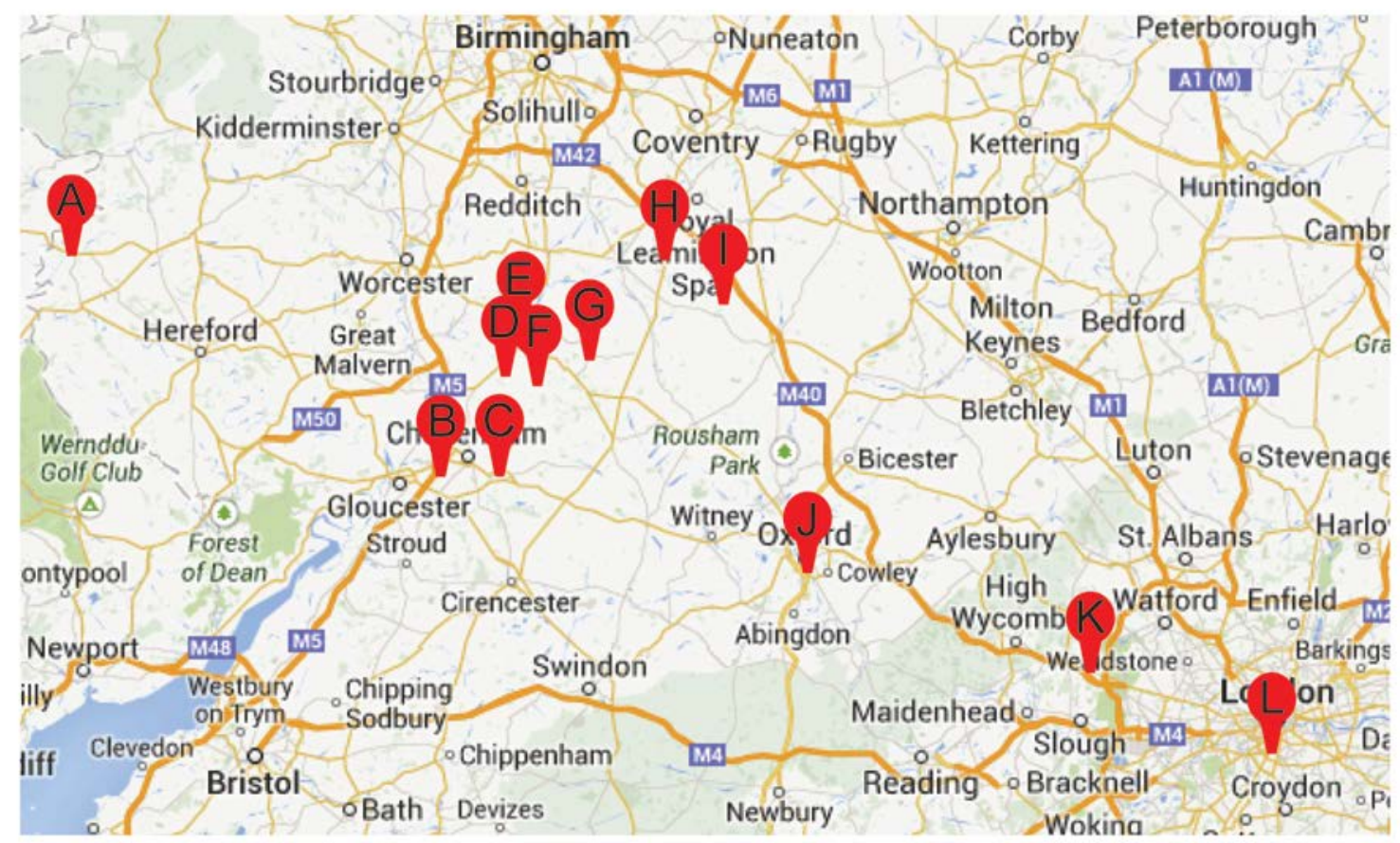

\section{FIGURE 1}

A: Kington, Herefordshire - Sarah Talbot

B: Badgeworth, Gloucestershire - Sarah Chapone

C: Dowdeswell, Gloucestershire - Sarah Chapone

D: Dumbleton, Gloucestershire - Sarah Chapone

E: Evesham, Worcestershire, Elizabeth Elstob and Anna Hopkins

F: Stanton, Gloucestershire - Sarah Chapone

G: Campden, Gloucestershire - George Ballard

$\mathrm{H}$ : Welsbourne (Wellesbourne), Warwickshire - Anne Dewes

I: Radway, Warwickshire - Sarah Talbot

J: Oxford - George Ballard

K: Bulstrode Park, Buckinghamshire - Elizabeth Elstob

L: Clapham, London - Anna Hopkins

Here the letters of the same six significant contributors to Ballard's letter book will be analysed - to gain a picture of the geographical reach of this epistolary network. ${ }^{63}$ These writers are Elizabeth Elstob, Anna Hopkins, Sarah Chapone, Sarah Talbot, Anne Dewes, and Mary Delany. Some of the letters in the volume have been excluded from this examination of geographical spread, in order to focus on the key points in Ballard's network - his most significant correspondents. Specifically, those letters that either do not form part of a series or, otherwise, are not addressed to Ballard himself have all been omitted from the analysis, examples of which include a message written by Sarah Chapone and addressed to Elizabeth Elstob, a copy of a letter from Henry Hastings to 
Chapone, four letters written by Elstob and addressed to Mr Rawlins, five letters written by several women to Reverend Dr Charlott; and ten miscellaneous letters penned by several letter-writers to various addressees. ${ }^{64}$ This analysis of the residences and movements of the letter-writers was only possible through a close examination of the material composition of the letter book. Instead of reading this correspondence solely for the messages it contains, the letters have been used to trace the locations, journeys, and timescales involved in this network's interactions with each other and the outside world.

The first, and most substantial, set of letters were written by Elizabeth Elstob and sent to George Ballard in his two different homes: Campden, Gloucestershire ${ }^{65}$ and, later, Magdalen College, Oxford. There are forty-two letters in total. Elstob initially wrote from her home in Evesham, Worcestershire and, later, from Bulstrode in Buckinghamshire and also London - when she was in residence with the Duke and Duchess of Portland. Between 1735 and 1739 (with the exception of one letter written from Bath), Elstob and Ballard communicated by post between their respective locations in neighbouring counties in the West of England. As the crow flies, there are just eight miles between Evesham and Campden ${ }^{66}$ and in her letters Elstob documents meeting Ballard three times in those four years.

The next most significant contributions to the letter book are twenty-eight letters written by Sarah Chapone and nine letters written by Anna Hopkins. Hopkins, like Elstob, lived in Evesham, Worcestershire and then later in Clapham, London and as this correspondence dates from 1741-53, most of her letters are sent to Ballard's Oxford address. Sarah Chapone's and Ballard's correspondence is wholly located within the county borders of Gloucestershire until Ballard moved away to Oxford, and dates from 1737-53. Indeed, Chapone had been born in Stanton, Gloucestershire, and married the vicar of a local parish: Childswyckham. ${ }^{67}$ By the date of the first of Chapone's letters to be included in Ballard's letter book, the Chapones had experienced financial difficulties and were amidst a series of moves within the surrounding area of Stanton and would not be fully settled again until 1745, when the Reverend John Chapone became vicar of Badgeworth, near Cheltenham. ${ }^{68}$ Chapone wrote from several Gloucestershire locations including Dumbleton, Dowdeswell in the Cotswolds, the Cheltenham area, Cheltenham itself, and a residence called Salisbury Court. So, until 1750 - when Ballard moved to Oxford - the Chapones lived no more than twenty miles, and more often closer to ten miles, from Campden (as the crow flies) and in relative proximity to Ballard.

Anna Hopkins lived in Evesham and was in close contact with Elizabeth Elstob, both during her time there and also after she moved to Clapham, in London. Anna Hopkins played an important role in finding subscriptions for Ballard's publishing project, Memoirs of Several Ladies and also provided Ballard with information and transcriptions which were useful to his research:

As the collector of Inscriptions, I thought the enclos'd might be agreeable to you, a gentleman translated it on purpose for $\mathrm{M}^{\mathrm{rs}}$ Dewes, who gave me leave to transcribe it for you, and desired I would sent it with her service. I should have been glad if I cou'd have sent you the Latin. ${ }^{69}$

There are five letters written to Ballard from Sarah Talbot who oscillated between living in Radway, Warwickshire fifteen miles east of Campden and Kington in 
Herefordshire, over fifty miles west of Campden and by far the farthest flung correspondent (aside from those writing from Ireland and London). Interestingly, Anne Dewes - who contributed ten letters to the volume - mainly wrote from Welsbourn (spelled Wellesbourne on modern maps) in Warwickshire, thirteen miles from Campden. Dewes posted one letter from a "Suffolk Street" address in 1754 - the most likely Suffolk Street being the address in London's west end located between Piccadilly Circus and Charing Cross.

The last correspondent, Mrs Delany, wrote two letters dated in the early 1750s and written from Delville, Delany's villa outside Dublin, Ireland. This example breaks with the mainstay of correspondents located within Gloucestershire or in the neighbouring counties of Worcestershire, Herefordshire or Warwickshire. For the majority of Ballard's life, Campden was his home and place of work and it was from this Gloucestershire market town that he built up his network of contacts. Some of the women who came into contact with Ballard and began to write to him knew other women in the same region, other women who might be keen to support his publishing project. Whilst the geography of Ballard's letter book included London, Bulstrode Park, and Delville House in Ireland, these were not prominent in the volume as a whole, where addresses in the West Country and West Midlands dominated. This analysis of the locations of Ballard's correspondents shows that, to a large extent, the epistolary network was composed of individuals who could also meet in person. Having said that, once a strong epistolary friendship was established, it could survive the distance placed between correspondents by a move - Elstob's removal to Bulstrode and Ballard's to Oxford being prime examples.

\section{The correspondence}

The compiled correspondence represents an imposing volume, but small material details contained in each letter betray useful information about the circumstances and motivations of the letter-writers. For example, as the pages are turned the remnants of gilt-edged paper can be seen on some of the letters, speaking to the greater prosperity of some correspondents over others. Even on the modest income of a school teacher, Elizabeth Elstob routinely afforded gilt edges to her letters, likewise Sarah Talbot. Anna Hopkins' missives offered a mixture of gilt and plain. ${ }^{70}$ Sarah Chapone, supporting a large family on a clergyman's wages, had the most strained household income which made large sheets of gilt-edged paper a luxury and, for the most part, her letters appeared on smaller pages, of rougher quality. Taken together, the material evidence of Ballard's letter book illuminates the realities of a provincial scholarly network - from the specifics of place, space and time to the experiences of body, mind and emotion.

Wax seals remain intact on some of the letters with periods of mourning marked by a shift in colour from red to black. For example, from December 1750 until December 1752, Sarah Chapone traded her red wax for black, the most likely explanation being the death of her elderly mother, Damaris Kirkham, in 1750.

Correspondence constitutes the vast majority of pages within this letter book, but here and there some other documents are attached. On 29 August 1735, Elizabeth Elstob included a "Specimen of Runick" written on parchment, ${ }^{71}$ noting in the accompanying letter: "knowing you to be a Lover of Antiquity, beg your Acceptance of a small Transcript from the Saxon, written I believe by the first Woman that has Studied that 
Language since it was spoke."72 Similarly, on 24 December 1736, Elstob enclosed "For The Rev ${ }^{\mathrm{d}} \mathrm{M}^{\mathrm{r}}$ Knight” a small transcription, again on parchment. ${ }^{73}$ Elstob explained:

I return you thanks for the sight of the inscription from that valuable piece of Antiquity. The Characters are undoubtedly Runick, but the little knowledge I once had in that Language, by a long disuse is almost lost, so that I dare not give any judgement upon it. $^{74}$

The use of parchment instead of paper for these short transcriptions of ancient languages was most likely the result of the preferable writing surface it offered. Whilst paper had become by far the most common writing surface in the eighteenth century, parchment might still be used for formal documents. Moreover, parchment could withstand the scraping off and re-writing of lines of ink, which may well have been a particular advantage in the careful transcription and circulation of ancient texts. ${ }^{75}$ The few pieces of parchment that remain amongst the paper letters in Ballard's collection speak to the traffic of objects and texts that accompanied correspondence and circulated amongst amateur collectors and writers of the eighteenth century.

Here, two of the correspondents least well known to history, Anna Hopkins and Sarah Talbot, will be examined to give a sense of the character of Ballard's female epistolary network. Hopkins wrote in a large, steady, italic hand, leaving no margin and filling her pages to the very edge. She was highly supportive of Ballard's work and her name is mentioned no fewer than seven times in Elstob's letters in relation to her efforts procuring subscriptions and sales of Ballard's book. Like other women in the network, Hopkins also provided Ballard with information about her family members for the purposes of his research. On 14 August 1741 she wrote:

I should be very glad if I could communicate any things that would be of service for carrying on the $\mathrm{La}[\mathrm{u}]$ dable work you mention; and tho' I can answer but very few of your queries, and those but in a very indifferent manner, I cannot refuse giving you an account of what I know concerning my Grand-father, whose Memory is dear to me, and indeed to everybody who knew his Worth. ${ }^{76}$

In the same letter Hopkins went on to describe the life and circumstances of "The Rev ${ }^{\mathrm{d}}$ $\mathrm{M}^{\mathrm{r}}$ Robert Hill” who "Tho he was a Learned and ingenious man, I never heard that he Publish'd any of his writings, if he had, I fancy my Mother must have known it."77 Hopkins offered to follow up the details of her grandfather's life and "write to my Uncle at Gloucester to get my Grand-fathers age out of the Register, and perhaps he may be able to solve the rest of your queries". ${ }^{78}$ Later the same year, Hopkins wrote to Ballard with news of a discovery that had been made at Gloucester Cathedral:

$\mathrm{M}^{\mathrm{rs}}$ Dewes writes me word that in the alterations they are making in the Cathedral at Gloucester, they have discover'd several Bodys in Stone Coffins (very entire, but as soon as the air comes to them, they crumble to dust. they suppose them to be Abbots by a Pastoral Staff and a Pewter Chalice they find buried, but there is no Inscription. If you can tell any circumstances about them, you will exceedingly oblige us both. ${ }^{79}$ 
The letters in Ballard's letter book routinely refer to his requests for transcriptions, books, or other pieces of information concerning the historical past. When the women were able to procure what Ballard needed, information passed swiftly and easily about the group and, likewise, where difficulties occurred, apologies were made: "Not being acquainted with $\mathrm{M}^{\mathrm{r}}$ Partridge the present Rector of Condicote, I do not know how to procure the Inscription." 80 But the network did not only facilitate Ballard's acquisition of things, but allowed for an exchange to take place between many of its participants, as this note in Hopkin's letter of November 1741 suggests:

I return you many thanks for the Charming Inscription you send me, $\mathrm{M}^{\mathrm{rs}}$ Dewes to whom I sent a copy of it, admires it as much as I do, and desires I would send her any thing more of the same sort that comes in my way. ${ }^{81}$

The surviving correspondence traces the lines of a much greater exchange of ideas, knowledge, materials and influence. And as a scribbled note at the end of one of Anna Hopkin's letters implies, this mutually supportive network provided its participants with an intellectual sociability that they highly valued:

we will come to Campden if possible. Your Curiosity, \& ingenious Conversation, will be a more valuable entertainment to us, than what we should meet with in the most Magnificent Palaces. ${ }^{82}$

Sarah Talbot's letters have one of the least standardised hands in the letter book - a loose italic style, written with space between the lines. As mentioned above, the 1775 edition of Memoirs was dedicated "To Mrs. Talbot of Kineton in Warwickshire”:

as an acknowledgement of my sincere and high regard for her and Mr. Talbot and as a small testimony of gratitude for extraordinary favours conferred by both of them upon their most obliged and most devoted humble servant George Ballard. ${ }^{83}$

Whilst William Talbot provided Ballard with valuable monetary support, it is Sarah Talbot's letters that survive in the letter book and testify to an involved and engaged correspondence between a vicar's wife and an antiquary. The letters reveal a regular exchange of books between Ballard and Talbot and despite Talbot's feeling that her views were confined to a "narrow circle" ${ }^{44}$, she wrote long and thoughtful responses to her reading:

Your parcel is just delivered into my hands, which from a liberty $\mathrm{M}^{\mathrm{r}}$ Talbot always allows me in his absence I have opened and find in it the book you was so good to promise me, which thro' your recommendation I dare depend upon great pleasure in reading. I shall give you my thoughts on it as soon as ever I have read it. $^{85}$

The book that caused Talbot's longest response was Mary Astell's Some Reflections Upon Marriage, first published in 1700. Interestingly, several years before lending the 
book to Talbot, Ballard had asked to borrow it from Anna Hopkins, who revealed that she - in turn - had borrowed it from Sarah Chapone:

I am sorry it is not in my power to send you $\mathrm{M}^{\mathrm{rs}}$ Astill's Proposal to the Ladies. I borrow'd it of $\mathrm{M}^{\mathrm{rs}}$ Chapon, and sent it home long ago, but I dare say she will very willingly lend it you. Tho' I knew that she was the Author of Hardships of English Laws \&c, I did not mention it to you because I thought it was a secret. ${ }^{86}$

Hopkin's reply also betrays the open secret that was Chapone's authorship of a related published work: The Hardship of the English Laws in Relation to Wives (1735) and documents the interest with which Ballard's female network engaged with issues around women's lives and rights. In a very long letter of 6 September 1746, Talbot reflected on Astell's work, beginning by saying:

I have with great pleasure read $\mathrm{M}^{\mathrm{rs}}$ Astells Reflections upon Marriage which you was so obliging to send me, and must own had they fallen into my hands before I entered the married State they would so far have alarmed me, as to have made me re-examine every motive before I durst have ventured into so sacred an engagment. ${ }^{87}$

What follows is a disquisition on religion, marriage and the relations between the sexes, strongly referencing Talbot's own experience of marriage, and acknowledging that she "had never fully considered the Natural Superiority in either Sex". Nevertheless, Talbot applied her mind to this topic in full in her letter to Ballard, writing:

let me therefore request that you, $\mathrm{S}^{\mathrm{r}}$, who are ingaged in the generous search after the happy few among our sex who have distinguished themselves from the rest by their learning, Piety, or usefullness in the world, would set their Characters in a more publick view than what you now intend them to encourage and raise an emulation in others, and to convince the world womens minds are capable of equal improvments when the same care, and cultivation is allowed to them. men 'tis true are called upon to fill up all the publick offices in the world; And therefore they appear to do greater good, or hurt according as they act in them but let it not be forgot, that the little circle women have to act in, is not so trifling as may be imagined; their example, and instructions will have some Influence, and may be considered not improperly as the little Wheel which sets larger ones in motion. ${ }^{88}$

Talbot's next lines spelled out the influential role women played in the education of the young, both girls and boys, and the consequent need for women's education and called for "Pride, impertinence, and disobedience" not to be considered the primary qualities of an educated woman. ${ }^{89}$ Many of the letters in Ballard's letter book focus on the collection of subscriptions and the passing of books and documents, but Talbot's epistle gives a rare insight into the life of the mind of a woman unknown to intellectual history and who did not leave her mark in the published record. 


\section{Conclusion}

Ballard's letter book presents the reader with a glimpse of a world of scholarly activity and intellectual companionship that dips below the radar of most intellectual histories of this period. Both materially and textually, the letter book is a physical remnant of an epistolary network that promoted the scholarship of its participants.

Complex relationships existed within this network but where inequalities existed, exchange was often justified on the grounds of progressing scholarship. As Rosemary Sweet describes, antiquarianism "did provide a language within which people from very different backgrounds could communicate and exchange information." 90 This scenario also helped those individuals who conceptualised their antiquarian activities as merely helping a more talented scholar in their pursuit of knowledge. Interesting social dynamics emerge from Ballard's letter book: the financially fallen Elizabeth Elstob, who was proud of her illustrious familial heritage, found herself grateful to have met a stay-maker who could connect her with a wider intellectual culture after a period of intellectual isolation. The powerful women, Mary Delany and the Duchess of Portland, are quietly present in this epistolary network, but the letters are written by the much lower status Sarah Chapone and Anna Hopkins. Doors were opened on the grounds of intellect, but not flung wide because to do so would have contravened the social code. In some cases, unseemly mixing of the social classes was purposely avoided and correspondence alone provided the connection, but for many of Ballard's female circle - social visits were a regular occurrence. Anne Dewes, Anna Hopkins, Sarah Chapone and Elizabeth Elstob all met with George Ballard when they could.

The relationships that are made visible by Ballard's letter book highlight the complex culture of intellectual friendship, collaboration, book-selling and patronage that fuelled eighteenth-century scholarly production. Whilst Ballard's network operated from the provinces and with little more than epistolary contact with mainstream antiquarian society, it still produced a body of work and provided personal gratification to its knowledge-hungry participants. The correspondence contained in this volume is representative of the intellectual space created by epistolary culture itself - an arena in which even the isolated could exchange their thoughts with others.

Returning to Ruth Perry's remark about Ballard being a man who "wrote about women who were, like him, perennial students, amateurs in the groves of academe" 91 George Ballard did not only write about such women, he was friends with them, exchanged ideas with them, and carefully preserved their letters - personally ensuring that they would join the distinguished manuscript collections of the Bodleian Library.

\footnotetext{
1 David Vaisey, “Ballard, George (1705/6-1755)”, Oxford Dictionary of National Biography (Oxford: Oxford UP, 2004).

2 Mechthild Gretsch, “Elstob, Elizabeth (1683-1756)”, ODNB (Oxford: Oxford UP, 2004); and Shaun F.D. Hughes, "Elizabeth Elstob (1683-1756) and the Limits of Women's Agency in Early Eighteenth-Century England”, in Jane Chance, ed., Women Medievalists and the Academy (Madison: University of Wisconsin Press, 2005) 3-24.

${ }^{3}$ B. Brandon Schnorrenberg, “Delany, Mary (1700-1788)”, ODNB (Oxford: Oxford UP, 2004).

${ }^{4}$ G. Ballard, Memoirs of Several Ladies of Great Britain (Oxford, 1752) v.
} 
${ }^{5}$ See William Dunn Macray, The Annals of the Bodleian Library (Oxford, 1890), footnote 1: 255: http://dbooks.bodleian.ox.ac.uk/books/PDFs/400523836.pdf - I am very grateful to Eva Oledzka (Western Manuscripts Reference Librarian at the Bodleian Library) for bringing this publication to my attention.

6 See the Bodleian Library collection level description for the Ballard Papers: http://www.bodley.ox.ac.uk/dept/scwmss/wmss/online/1500-1900/ballard/ballard.html; Ballard had left his papers well ordered and fully indexed ready for transfer to the Library's holdings, see Macray, Annals 2546 and also the note to this effect on p. 147 of J. Walker and P. Bliss, eds, Letters Written by Eminent Persons in the Seventeenth and Eighteenth Centuries, 2 vols. (1813) 2.

${ }^{7}$ See, for example, R. Perry,ed., Memoirs of Several Ladies of Great Britain (Detroit: Wayne State UP, 1985), Margaret J. M. Ezell, Writing Women's Literary History (Baltimore: The John Hopkins UP, 1993) and Rosemary Sweet, Antiquaries: the Discovery of the Past in Eighteenth-Century Britain (London: Hambledon and London, 2004).

8 J. A. I. Champion, "Enlightened Erudition and the Politics of Reading in John Toland's Circle," The Historical Journal 49:1 (2006): 111-141 (138). See also Jenny Uglow, The Lunar Men: Five Friends Whose Curiosity Changed the World (New York: Farrar, Straus and Giroux, 2002).

${ }^{9}$ Sweet, Antiquaries xviii.

${ }^{10}$ Ibid. 36-8.

${ }^{11}$ Sweet, Antiquaries 44; examples include Surrey solicitor William Bray (1736-1832), and Bristol surgeon William Barrett (1727?-1789) and, likewise, many clergymen joined the ranks of antiquarianism.

${ }^{12}$ A good example on both counts being the poet Ann Yearsley, nicknamed "the Bristol Milkwoman", who successfully sourced the financial support of patrons, most notably Hannah More, to further her literary career, see M. Waldron, "Yearsley, Ann (bap. 1753, d. 1806)”, ODNB (Oxford: Oxford UP, 2004).

${ }^{13}$ Ballard completed the account in 1731 and it was presented to the Society of Antiquaries sixteen years after his death in 1771, see Vaisey, "Ballard, George".

${ }^{14}$ Ballard was admitted to read in the Bodleian on 9 December 1747, when he was over 40 years old, see Vaisey, "Ballard, George".

${ }^{15}$ Sweet, Antiquaries 61.

${ }^{16}$ This was the case for many provincial antiquaries who relied on news by letter of discussions held at the Society of Antiquaries or recent publications on points of interest, see Sweet, Antiquaries 54.

${ }^{17}$ Within the letter book there is evidence not only of the correspondents seeking support for Ballard's publication, but one letter-writer - Sarah Chapone - also actively campaigned for financial help for the scholar, Elizabeth Elstob, who had fallen on hard times.

${ }^{18}$ Samuel Johnson's criticism of Lord Chesterfield being cited as a key example of the breakdown of the patronage system.

${ }_{19}$ Paul J. Korshin, “Types of Eighteenth-Century Literary Patronage,” Eighteenth-Century Studies 7:4 (1974): 453-73 (473).

${ }^{20}$ Dustin Griffin, Literary Patronage in England, 1650-1800 (Cambridge: Cambridge UP, 1996) 10-11.

${ }^{21}$ Ibid. 11.

${ }^{22}$ Rosemary Sweet has also argued that much antiquarian subscription publishing " made a selling point of the limited size of the print run, and promised no more would be published than subscribed for" on account of cheap volumes decreasing the "social cachet" of both the books and the subject matter, Antiquaries 31-2.

${ }^{23}$ See David Hunter, "The Publishing of Opera and Song Books in England, 1703-1726," Notes 47:3 (1991) 647-85 and Margaret Seares, "The Composer and the Subscriber: a Case Study from the $18^{\text {th }}$ Century,” Early Music 39:1 (2011) 65-78; authors might have a private income, secure a grant or a loan from a patron, or plough the profits of a previous project into the publication.

${ }^{24}$ Another, more contemporary, example was the working woman and poet Mary Leapor who secured the support of a local educated woman who campaigned in favour of publishing Leapor's work. Leapor's poetry was eventually published posthumously, by subscription, in 1748 and 1751, see Stuart Gillespie, “ Leapor, Mary (1722-1746)”, ODNB (Oxford: Oxford UP, 2004) and Griffin, Literary Patronage 189-203.

${ }^{25}$ See S. J. Skedd, “More, Hannah (1745-1833)”, ODNB (Oxford: Oxford UP, 2004).

${ }^{26}$ Emma E. Pink has explored Frances Burney's use of her own cultural capital to successfully publish by subscription, but naturally if an author lacked this ability to navigate the literary marketplace for themselves, they could secure the support of a culturally well-connected individual, such as Hannah More, see Emma E. Pink, "Frances Burney's Camilla: 'To Print My Grant Work ... By Subscription'," Eighteenth-Century Studies 40:1 (2006) 51-68 (52). 
${ }^{27}$ F. Felsenstein, "Ann Yearsley and the Politics of Patronage - the Thorp Arch Archive, Part I," Tulsa Studies in Women's Literature, 21:2 (2002) 346-92.

${ }^{28}$ Ibid. 384.

${ }^{29}$ Ibid.

${ }^{30}$ Vaisey, "Ballard, George”.

${ }^{31}$ Ibid.

${ }^{32}$ See Sweet, Antiquaries 60-1 for more on the difficulties of Ballard's social status in terms of both his relationship with gentleman scholars and his broader pursuit of antiquarian study.

${ }^{33}$ See Susan M. Pearce, “Antiquaries and the Interpretation of Ancient Objects, 1770-1820," Visions of Antiquity: the Society of Antiquaries of London 1707-2007, ed. Susan M. Pearce (London: Society of Antiquaries London, 2007) 147-8 - she calculates that around 13\% of the Society's members were clergy, ranging from bishops to local parish incumbents.

${ }^{34}$ A notable exception being Peter Muilman - but he was ultimately accused of using the Society to advance his own commercial interests and was expelled, see Pearce, “Antiquaries” 147-8.

${ }^{35}$ See Sweet, Antiquaries 36.

${ }^{36}$ Perry, Memoirs 13.

${ }^{37}$ Anna Hopkins was a particularly effective recruiter of subscriptions.

${ }^{38}$ Bodleian, Ballard 43, f. 5: Elizabeth Elstob to George Ballard, 29 Aug. 1735.

${ }^{39}$ George Ballard writing to Charles Lyttelton on 22 May 1753, defending his intentions in writing Memoirs after reading the harsh words of several critics, as reproduced in Walker and Bliss, Letters 146-7.

${ }^{40}$ H.E. Salter, ed., Remarks and Collections of Thomas Hearne, 11 vols. (Oxford, 1921) 11: 19. The preface to this volume notes that many of the entries in Hearne's diary were taken verbatim from correspondence he had received.

${ }^{41}$ Ibid. 74.

${ }^{42}$ Ibid.

${ }^{43}$ Ezell, Writing Women's Literary History 79.

${ }^{44}$ Ibid. 78-81, 86-8.

${ }^{45}$ See also Paul Salzman, Reading Early Modern Women's Writing (Oxford: Oxford UP, 2006) 1-3.

${ }^{46}$ Perry, Memoirs 12.

${ }^{47}$ Ezell, Writing Women's Literary History 85.

${ }^{48}$ Ballard, Memoirs titlepage.

${ }^{49}$ Perry, Memoirs 13.

50 John Leland was a poet and antiquary, see James P. Carley, "Leland, John (c.1503-1552)”, ODNB (Oxford: Oxford UP, 2004).

${ }^{51}$ John Bale was an historian and scholar, see John N. King, "Bale, John (1495-1563)”, ODNB (Oxford: Oxford UP, 2004).

52 John Pits was a Roman Catholic priest and scholar, see F. Blom and J. Blom, "Pits, John (15601616)", ODNB (Oxford: Oxford UP, 2004).

${ }^{53}$ Ballard, Memoirs 98.

${ }^{54}$ Carley, "Leland, John".

${ }^{55}$ King, "Bale, John".

${ }^{56}$ Walker and Bliss, Letters 145.

${ }^{57}$ For the dedication to Talbot, see Ballard, Memoirs iv and for Delany see 242. As noted in Vaisey, "Ballard, George": "The section of the work which covers the fifteenth and sixteenth centuries is dedicated to the wife of the Revd William Talbot 'as a small testimony of gratitude for extraordinary favours' conferred on Ballard by herself and her husband; the section covering later centuries is dedicated to Mrs Mary Delany, 'the truest judge and brightest pattern of all the accomplishments which adorn her sex'.”

${ }^{58}$ See, for example, Sylvia Harcstark Myers, Bluestocking Circle: Women Friendship and the Life of the Mind in Eighteenth-Century England (Oxford: Clarendon, 1990) 131-3, Norma Clarke "Elizabeth Elstob (1674-1752): England's First Professional Woman Historian?” Gender \& History 17:1 (2005) 210-20; and Norma Clarke, The Rise and Fall of the Woman of Letters (London: Pimlico, 2004).

${ }^{59}$ Thomas Keymer, “Chapone, Sarah (1699-1764)” ODNB (Oxford: Oxford UP, 2004).

${ }^{60}$ Brandon Schnorrenberg, "Delany, Mary”.

${ }^{61}$ Harcstark Myers, Bluestocking Circle 130. 
${ }^{62}$ Bodl., Ballard 43, f. 101: Anna Hopkins to George Ballard, 14 Aug. 1741. "Bradley-Green” is a village in Worcestershire.

${ }^{63}$ The locations of all correspondents have been plotted on a Google map, see link: https://maps.google.com/maps/ms?msid=212719904199717717016.0004dcacdfb0f7ea635e2\&msa=0\&ll=5 $1.910391,-1.230469 \&$ spn $=1.494385,3.532104$.

${ }_{64}$ The miscellaneous letters include letters from Mary Turner (Oxfordshire), Lady C. Fox (Chiswick, London), A. Trenchard (unknown origin), George Ballard (Campden or Oxford), Anne Donnellan (London), Agnes Keate (unknown origin), Elizabeth Gray (unknown origin), and an older letter dating from 1579 from Anne Dudley (unknown origin). The addressees were Thomas Rowney (London), an unknown person (Hammersmith, London), George Ballard (Campden), Mrs Talbot (Kington, Warwickshire), George Ballard (Oxford), 'Reverend Sir' (unknown origin), and the 1579 letter is written to Lady Malbie (unknown origin).

${ }^{65}$ Ballard's "Campden" is referred to on modern maps as "Chipping Campden".

${ }^{66} 12$ miles by land transport today. Although, Harcstark Myers, in Bluestocking Circle reports the distance as just five miles - she probably does so on the basis of a letter written by Elizabeth Elstob to Ballard on the 18 June 1737, in which Elstob comments that it is the first time she can remember "that ever I rid 5 miles to see a Gentleman.”, Bodl., Ballard 43, f. 42.

${ }^{67}$ See Keymer, "Chapone, Sarah”.

${ }^{68}$ Ibid.

${ }^{69}$ Bodl., Ballard 43, f. 101: Anna Hopkins to George Ballard, 14 Aug. 1741.

${ }^{70}$ Many of Anna Hopkins' letters have damaged edges and so it is difficult to be sure about the presence of gilt edges.

${ }^{71}$ Parchment is a writing surface made of animal hide, usually from a sheep, goat or calf's skin, which can be written upon on both sides and provides an excellent writing surface for a quill pen. Elstob's transcription is written on one side of a page of parchment in a clear, well-spaced script, Bodl., Ballard 43, f. 6.

${ }^{72}$ Bodl., Ballard 43, f. 5v: Elizabeth Elstob to George Ballard, 29 Aug. 1735.

${ }^{73}$ Bodl. Ballard 43, f. 31.

${ }^{74}$ Bodl., Ballard 43, f. 31: Elizabeth Elstob to George Ballard, 24 Dec. 1736.

${ }^{75}$ See Michael Finlay, Western Writing Implements in the Age of the Quill Pen (Carlisle: Plain Books, 1990) 28-9.

${ }^{76}$ Bodl., Ballard 43, f. 100: Anna Hopkins to George Ballard, 14 Aug. 1741.

${ }^{77}$ Ibid.

${ }^{78}$ Ibid.

${ }^{79}$ Bodl., Ballard 43, f. 103: Anna Hopkins to George Ballard, 16 Nov. 1741.

${ }^{80}$ Ibid., f. 101.

${ }^{81}$ Bodl., Ballard 43, f. 103: Anna Hopkins to George Ballard, 16 Nov. 1741.

${ }^{82}$ Ibid.

${ }^{83}$ Ballard, Memoirs (1775), frontispiece.

${ }^{84}$ See two similar comments to this effect in Bodl., Ballard 43, f.193: Sarah Talbot to George Ballard, c.1747 and f. 194: same to same, 31 Mar. 1747.

${ }^{85}$ Bodl., Ballard 43, f.193: Sarah Talbot to George Ballard, c.1747.

${ }^{86}$ Bodl., Ballard 43, f. 106: Anna Hopkins to George Ballard, 14 Dec. 1741.

${ }^{87}$ Bodl., Ballard 43, f. 197: Sarah Talbot to George Ballard, 6 Sep. 1746.

${ }^{88}$ Bodl., Ballard 43, f. 199: same to same, 6 Sep. 1746.

${ }^{89}$ Ibid., ff. 199-200.

${ }^{90}$ Sweet, Antiquaries 60.

${ }^{91}$ Perry, Memoirs 13. 